\title{
Assessment of Cryptophyceae ingestion by copepods using alloxanthin pigment: a caution
}

\author{
Elvire Antajan ${ }^{1,3, *}$, Stéphane Gasparini ${ }^{2}$ \\ ${ }^{1}$ Laboratorium voor Ecologie en Systematiek, Vrij Universiteit Brussel, Pleinlaan 2, 1050 Brussel, Belgium \\ ${ }^{2}$ Laboratoire d'Océanographie de Villefranche, BP 28, 06234 Villefranche-sur-Mer Cedex, France \\ ${ }^{3}$ Present address: Université du Littoral Côte d'Opale, 32 avenue Foch, 62930 Wimereux, France
}

\begin{abstract}
The accessory pigment alloxanthin is a well-known taxonomic marker for Cryptophyceae in natural seawater. The use of alloxanthin to estimate in situ zooplankton grazing and selectivity on Cryptophyceae was studied using 2 dominant copepods of the southern North Sea, Temora longicornis and Centropages hamatus. High-performance liquid chromatography (HPLC) analyses of water samples and of freshly caught copepods, starvation experiments, and feeding experiments (shipboard bottle-incubations) were carried out. Although alloxanthin was always detected in copepod extracts, (1) no correlation was found with alloxanthin in seawater, and (2) no significant grazing on Cryptophyceae was observed. Results of our gut-evacuation experiments showed that at least $78 \%$ of the initial alloxanthin content of $T$. longicornis and C. hamatus remained after $90 \mathrm{~min}$, whereas fucoxanthin and chloropigments decreased rapidly with time. Alloxanthin and astaxanthin esters were the only pigments remaining in the body of T. longicornis after several hours' starvation. It is concluded that most of the detected alloxanthin did not originate from the gut but from the body tissues. Our results suggest that alloxanthin is not suitable as a biomarker for quantitative or qualitative estimates of copepod grazing on Cryptophyceae.
\end{abstract}

KEY WORDS: Alloxanthin · Cryptophyceae $\cdot$ Copepod ingestion · HPLC

\section{INTRODUCTION}

In the North Sea, phytoplankton spring blooms consist mainly of Bacillariophyceae and Haptophyceae (Reid et al. 1990). Consequently, the ecological importance of these algae (Lancelot et al. 1998, Rousseau et al. 2002) as well as their contribution to zooplankton diet (Daro 1988, Fransz et al. 1991, Gasparini et al. 2000) have been extensively studied. In contrast, the presence of small flagellates (e.g. green algae and cryptomonads) has been less well documented. The main reasons are (1) lack of morphologic distinctive features of these algae and (2) damage caused during fixation that renders identification by classical microscopic methods difficult. Partly to overcome these problems, a chemotaxonomic approach based on detection of taxon-specific pigments by high-performance liquid chromatography (HPLC) has been used since the 1980s and is commonly employed to distinguish the main algae classes (see review in Jeffrey et al. 1999). Using this technique, the abundance and sometimes dominance of Cryptophyceae in natural seawater samples of the North Sea has been documented by the presence of alloxanthin pigment, a specific cryptomonad carotenoid (Gieskes \& Kraay 1983, 1984, Brunet et al. 1996, Breton et al. 2000). In parallel, several studies on the natural diet of zooplankton have reported the presence of alloxanthin in copepod extracts, leading to the suggestion that Cryptophyceae contribute to the diet of these crustaceans (Pandolfini et al. 2000) and could even be strongly selected (Breton et al. 1999, Cotonnec et al. 2001). Meanwhile, the use of carotenoid pigments to study zooplankton grazing and selectivity has been challenged during the last decade because of their possible degradation into unidentified pigments and/or colourless products during 
gut-passage. Descy et al. (1999) for instance, estimated that $91 \%$ fucoxanthin, $88 \%$ diadinoxanthin, $79 \%$ lutein and $71 \%$ alloxanthin were lost during gut passage in laboratory experiments conducted with the freshwater copepod Diaptomus minutus. Likewise, Kleppel (1998) showed that 60 to $100 \%$ fucoxanthin was lost during gut-passage in experiments conducted with the marine copepods Acartia californiensis and Calanus pacificus and concluded that it is necessary to exercise caution when attempting to use carotenoid pigments quantitatively.

In this paper, we focused on the in situ ingestion of Cryptophyceae by 2 dominant copepods of the southern North Sea, Temora longicornis and Centropages hamatus. HPLC analyses of water samples and of freshly caught copepods, starvation experiments and feeding experiments (shipboard bottle-incubations) were performed. Our results challenge the use of alloxanthin as quantitative and as qualitative indicator of Cryptophyceae ingestion by copepods.

\section{MATERIALS AND METHODS}

Sample collection. Sampling and experiments were carried out on board the RVs 'Belgica' and 'Zeeleeuw' in the relatively shallow (mean depth $24 \mathrm{~m}$ ) Belgian coastal zone (Fig. 1). Cruises were conducted at differ-

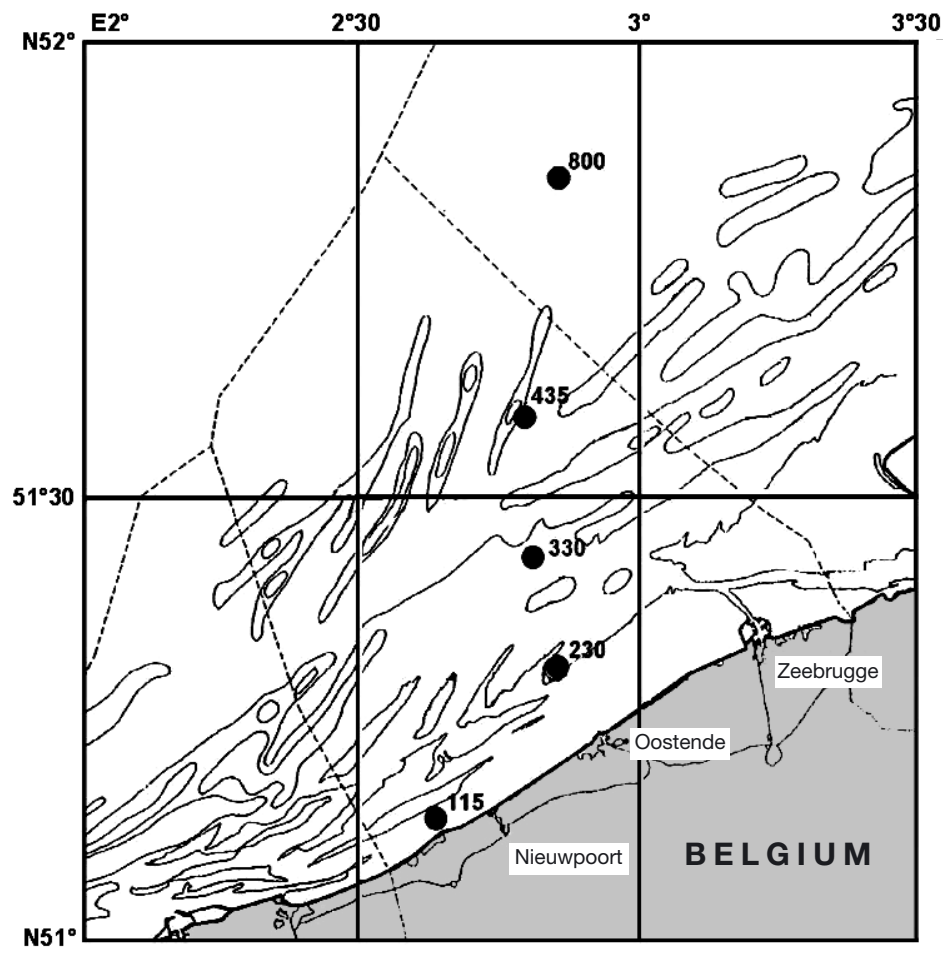

Fig. 1. Belgian coastal zone, showing location of the 5 stations sampled during the AMORE 1998-2001 cruises ent time intervals, including all seasons, from 1998 to 2001 as part of the AMORE (Advanced Modelling and Research on Eutrophication) project.

Water samples were taken with a $10 \mathrm{l}$ Niskin bottle from the subsurface, middle and near the bottom of the water column. Seawater subsamples $(250-1500 \mathrm{ml})$ from the different depths were immediately filtered in triplicate using GF/F glass-fibre filters ( $47 \mathrm{~mm}$ diameter, $0.7 \mu \mathrm{m}$ nominal pore size). All filters were folded in an aluminium foil and immediately stored in liquid nitrogen for HPLC pigment analysis. The rest of the seawater samples were then used for feeding experiments with copepods after mixing the water from the 3 depths (see later subsection).

Zooplankton samples were collected using a $200 \mu \mathrm{m}$ mesh WP-2 plankton net which was towed obliquely between the surface and bottom (tow duration $<5 \mathrm{~min}$ ). From each zooplankton sample collected in 2000 and 2001, a subsample was taken with a $200 \mu \mathrm{m}$ net, wrapped in aluminium foil, and frozen immediately in liquid nitrogen for analysis of the in situ pigment content of adult copepods by HPLC.

Evacuation experiment. In January 1998 and June 2001, evacuation experiments were carried out to determine the fate of pigments during gut passage. Immediately following capture, the copepods were sieved through a $1 \mathrm{~mm}$ mesh onto a $500 \mu \mathrm{m}$ mesh, rinsed with filtered $(0.7 \mu \mathrm{m})$ seawater, and transferred into a $25 \mathrm{l}$ aquarium of filtered seawater at ambient temperature. In January 1998 the starvation experiment was performed at $6.3^{\circ} \mathrm{C}$, whereas in June 2001 it was performed at $15.7^{\circ} \mathrm{C}$ and corresponded to the period of alloxanthin maximum in water samples. Copepod subsamples were removed and frozen immediately in liquid nitrogen at 10 min intervals during a 100 min experiment in 1998 and at 5 to 15 min intervals during a $90 \mathrm{~min}$ experiment in 2001. An additional starvation experiment of $3 \mathrm{~h}$ was performed in June 1998 for studying copepod pigments.

Feeding experiment. A total of 71 experiments to quantify grazing by Temora longicornis and Centropages hamatus and determine the fate of their prey in natural assemblages were performed from 1998 to 2001. For each experimental treatment, 30 adult copepods of the same species were selected, using a Pasteur pipette under a binocular microscope, and transferred into $500 \mathrm{ml}$ of natural seawater. Incubation started within $1 \mathrm{~h}$ of zooplankton collection and only individuals with normal swimming behaviour were selected. We immediately fixed 3 replicates of seawater (initial condition) in $1 \%$ glutaraldehyde (final concentration), while 3 replicates without copepods (control treatments) and 2 to 4 replicates with copepods (experimental treatments) were incubated for $24 \mathrm{~h}$. All treatments were incubated in on-desk incubators with 
water circulation to maintain ambient temperature. At the end of the incubation, we checked that the copepods were still alive, and the replicates were fixed with $1 \%$ glutaraldehyde.

Sample analysis. Upon return to the laboratory, all samples for HPLC analysis were stored in a freezer at $-85^{\circ} \mathrm{C}$ for no longer than 6 mo before analysis.

Samples for seawater pigment analysis were cut into small pieces (several $\mathrm{mm} \times 1 \mathrm{~cm}$ ) and sonicated in centrifuge tubes (on crushed ice), with $2 \mathrm{ml}$ of $100 \%$ cold acetone for $2 \times 15 \mathrm{~s}$ at $50 \mathrm{~W}$ using a Labsonic sonicator equipped with a $4 \mathrm{~mm}$ diameter probe inserted directly into the solvent. After sonication, samples were kept in the dark for $2 \mathrm{~h}$ at $4^{\circ} \mathrm{C}$ before centrifuged for $3 \mathrm{~min}$ at about $700 \times g$. Supernatants were filtered onto $0.5 \mu \mathrm{m}$ (Millex SR syringe equipped with $25 \mathrm{~mm}$ filter of $0.5 \mu \mathrm{m}$ porosity), transferred to $1 \mathrm{ml}$ vials and placed into the autosampler (kept at $4^{\circ} \mathrm{C}$ ) prior to injection of $100 \mu$ l extract through the HPLC column.

Samples for copepod pigment analysis were rinsed with cold filtered seawater and placed under a binocular microscope under dim light. We sorted 3 replicates of 50 adult copepods per species and placed them into $500 \mu \mathrm{l}$ of $90 \%$ cold acetone. Replicates were then macerated with tissue grinders, while being held on crushed ice. After thorough grinding, they were refrigerated in the dark for $2 \mathrm{~h}$, filtered on a syringe filter (Acrodisc CR PTFE $0.45 \mu \mathrm{m}$ ) to remove suspended particles, and $200 \mu \mathrm{l}$ of extract were injected into the HPLC system.

Reversed-phase HPLC analyses were conducted based on the slightly modified ternary gradient method of Wright et al. (1991) as described in Gasparini et al. (2000). Pigments were detected by absorption at $436 \mathrm{~nm}$ and identified based on comparison of their retention time and spectra with standards. Highpurity HPLC standards for chlorophyll $a$, pheophytin $a_{\text {, }}$ chlorophyll $c_{3}$, fucoxanthin, alloxanthin, peridinin and 19'hexanoyloxyfucoxanthin were obtained from the International Agency for ${ }^{14} \mathrm{C}$ determination (Horsholm, Denmark). Phaeophorbide a was obtained from ICN Biomedicals. Other carotenoids were identified using retention time and spectra of well-characterised pigments (Jeffrey et al. 1997).

After pre-concentration following the method of Colijn et al. (1990) for phytoplankton and microzooplankton enumeration (see also Gasparini et al. 2000), samples from the feeding experiments were analysed by an inverted microscope provided with phase contrast (ZEISS Sedival) in $5 \mathrm{ml}$ sedimentation chambers. Depending on cell density, random fields (60 to 100) or selected transects of the entire sedimentation chamber were counted for microplankton $(\times 200)$ and small flagellates $(\times 400)$. Clearance rates (volume swept clear of prey animal ${ }^{-1}$ unit time ${ }^{-1}$ ) were quantified from the difference in prey concentration determined between control and experimental treatments, using Frost's (1972) equations. Ingestion rates were calculated per copepod species for each potential prey by multiplying clearance rates with the corresponding prey biomass in the water. Prey enumeration and biomass were estimated from the seawater samples fixed at initial conditions. The carbon content of diatoms was calculated on the basis of cell density and biometry determined for each species. A specific average biovolume of a cell population was measured throughout the period of its development (Rousseau et al. 2002, and pers. comm.). After application of the correction equation for fixation-induced volume change (Menden-Deuer et al. 2001), the biovolumes were converted into carbon biomass using the size-dependent density relationship recommended for diatoms by Menden-Deuer \& Lessard (2000). Dinoflagellate, nanoflagellates and ciliates biomass were calculated by using carbon to volume relationships recommended by Menden-Deuer \& Lessard (2000). Colonial Phaeocystis globosa cells were free in our samples due to the dissolution of the colony matrix by the preserving agent. A conversion factor of $14.2 \mathrm{pg} \mathrm{C}$ cell $^{-1}$ for colonial cells and of $10.8 \mathrm{pg} \mathrm{C}$ cell $^{-1}$ for flagellated cells (microzoospores) was used to estimate P. globosa carbon biomass as recommended by Rousseau et al. (1990).

\section{RESULTS}

Fig. 2 shows seasonal variations in alloxanthin concentration integrated over the water column at different stations in the Belgian coastal zone in 2000 and 2001. Alloxanthin concentration varied between 0 and $0.44 \mu \mathrm{g} \mathrm{l}^{-1}$, with maximum values observed from endMay to June 2001. The concentration of alloxanthin was significantly correlated with Cryptophyceae abundance (Fig. 3). A bloom of Cryptophyceae was observed at end of May 2001, when their abundance increased from a background level of $<20 \mathrm{cells} \mathrm{ml}^{-1}$ to a maximum of 1060 cells $\mathrm{ml}^{-1}$.

In copepods, the alloxanthin content was generally higher in Temora longicornis than in Centropages hamatus (Mann-Whitney $U$-test: $U=45, \mathrm{n}_{1}=47$, $\mathrm{n}_{2}=22, \mathrm{p}<0.001$ ) (Fig. 4). The mean alloxanthin content of $T$. longicornis varied between 0.059 and $0.753 \mathrm{ng}$, with maximum values measured at the beginning of spring and in summer (>0.45 ng ind. $\left.{ }^{-1}\right)$. In C. hamatus, alloxanthin values were between 0.011 and 0.219 ng ind. ${ }^{-1}$. Alloxanthin content was not significantly correlated with the alloxanthin concentration in the seawater (Fig. 5) for either T. longicornis (Spearman's rank $R_{S}=0.251, \mathrm{n}=47, \mathrm{p}>0.05$ ) or $C$. hamatus $\left(R_{S}=-0.075, \mathrm{n}=22, \mathrm{p}>0.05\right)$. 


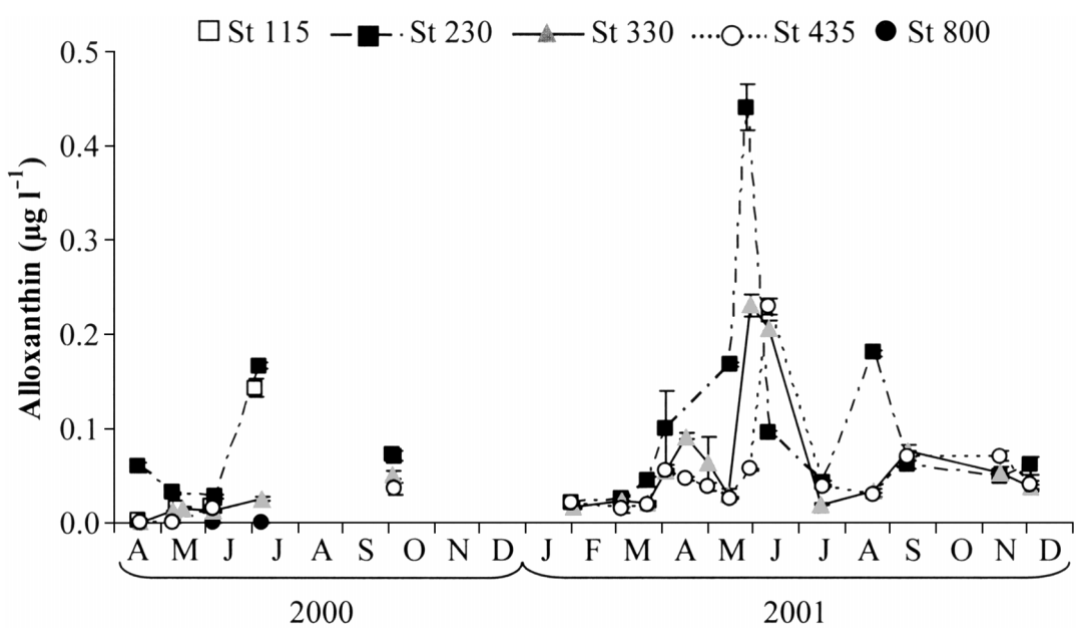

Fig. 2. Seasonal variations in alloxanthin concentration (mean $\pm \mathrm{SE}$ ) at 5 stations in Belgian coastal zone during the AMORE 2000-2001 cruises

experiments (Fig. 6a,c). Phaeophytin a was not always apparent in absorbance chromatograms analysed at $436 \mathrm{~nm}$ because its absorption is low at this wavelength. However, it was clearly visible on fluorescence chromatograms (not shown). After $90 \mathrm{~min}$ of starvation chloropigments and fucoxanthin were no longer detected in Temora longicornis (Fig. 6b), nor diadinoxanthin in Centropages hamatus (Fig. 6d). In June 1998, alloxanthin and astaxanthin esters were the only pigments remaining in the body tissues of $T$. longicornis after $3 \mathrm{~h}$ of starvation (not shown). Among the identified pigments, fucoxanthin, alloxanthin and chloropigments are commonly used as phytoplanktonic

As shown by the typical absorbance chromatograms obtained from HPLC analysis of copepod extracts in June 2001, fucoxanthin, diadinoxanthin, alloxanthin, diatoxanthin, chlorophyll $a$ and astaxanthin esters were detected in copepods at the beginning of starvation

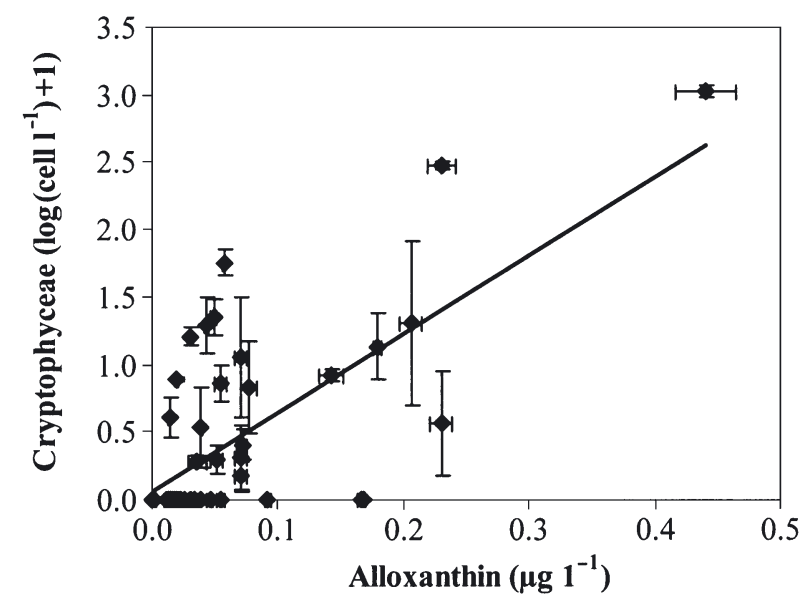

Fig. 3. Relation between alloxanthin concentration and Cryptophyceae abundance (mean $\pm \mathrm{SE}$ ) in Belgian coastal waters during the AMORE 2000-2001 cruises. Straight line: regression obtained by least-squares method (Spearman's rank $\left.R_{S}=0.592, \mathrm{n}=51, \mathrm{p}<0.001\right)$ biomarkers. Diadinoxanthin and diatoxanthin, which are not class-specific, will not be considered here. The results of the 2 starvation experiments are shown in Figs. $7 \& 8$ for winter and summer, respectively. The loss of the phytoplanktonic biomarker pigments during the starvation experiments showed different pattern among pigments. Fucoxanthin (a marker of diatoms and golden-brown flagellates) disappeared completely from the copepod's body after 10 min starvation. Chlorophyll $a$ and pheophytin a contents of $T$. longicornis and $C$. hamatus also decreased, but faster in summer than in winter. Less than $30 \%$ of the initial value in chlorophyll a remained in copepods after 10 min starvation in June 2001, whereas in January 1998 this occurred after $1 \mathrm{~h}$ incubation. In contrast to the other pigments, alloxanthin decreased little or not at all over time. In January 1998, the alloxanthin content of $T$. longicornis fell to $46 \%$ of the initial value after $20 \mathrm{~min}$ before increasing and remaining above $70 \%$ until the end of the starvation experiment (Fig. 7). In June 2001, the alloxanthin content decreased to 45 and $43 \%$ of the initial value after $60 \mathrm{~min}$ in T. longicornis and C. hamatus, respectively. In all experiments, the alloxanthin content of the copepods body tissues represented at least $78 \%$ of the initial value in alloxanthin after 90 min evacuation.

Table 1. Temora longicornis $(T)$ and Centropages hamatus $(C)$. Number of experiments in which significant grazing rates $(t$-test, $\mathrm{p}<0.05)$ were recorded for different prey items and copepod species

\begin{tabular}{|c|c|c|c|c|c|c|c|c|c|c|c|c|}
\hline & \multicolumn{2}{|c|}{ Bacillariophyceae } & \multicolumn{2}{|c|}{ Haptophyceae } & \multicolumn{2}{|c|}{ Cryptophyceae } & \multicolumn{2}{|c|}{ Prasinophyceae } & \multicolumn{2}{|c|}{ Dinophyceae } & \multicolumn{2}{|c|}{ Ciliophora } \\
\hline & $T$ & $C$ & $T$ & C & $T$ & $C$ & $T$ & $C$ & $T$ & $C$ & $T$ & $C$ \\
\hline Total no. of experiments & 48 & 23 & 48 & 23 & 48 & 23 & 48 & 23 & 48 & 23 & 48 & 23 \\
\hline Significant ingestion & 37 & 14 & 0 & 0 & 0 & 0 & 0 & 0 & 15 & 6 & 9 & 7 \\
\hline Non-significant ingestion & 11 & 9 & 48 & 23 & 48 & 23 & 48 & 23 & 33 & 17 & 39 & 16 \\
\hline
\end{tabular}


Among the 71 feeding experiments (Table 1: 48 with Temora longicornis and 23 with Centropages hamatus), significant ingestion rates were recorded for diatoms, dinoflagellates and ciliates. In contrast, we found no significant ingestion of Cryptophyceae or other nanoflagellates (Haptophyceae and Prasinophyceae). Detailed analysis of these grazing experiments has not been included here, since we are focusing on the Cryptophyceae.

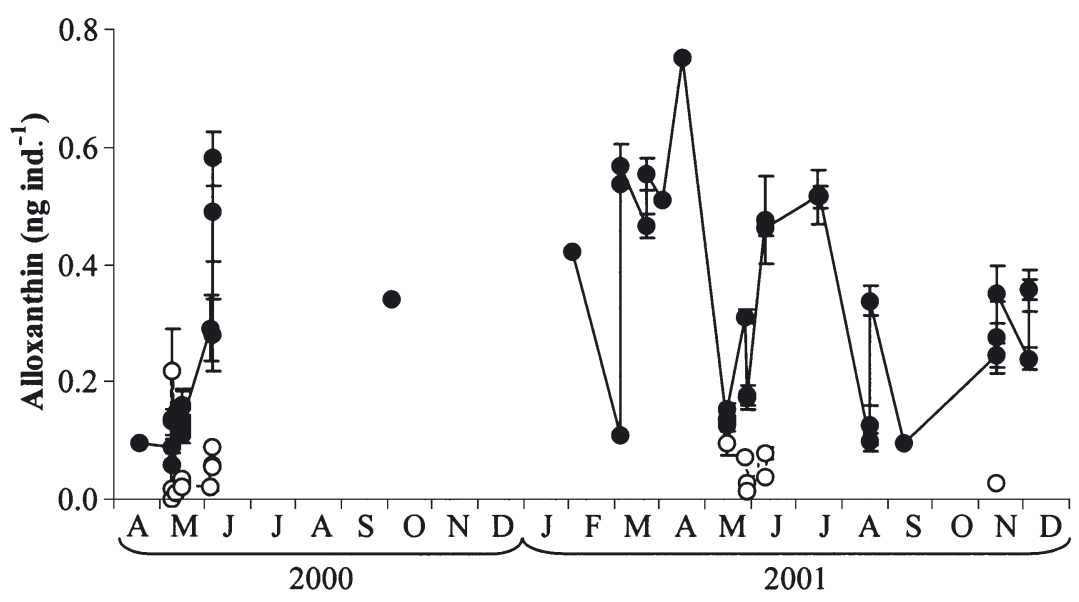

Fig. 4. Temora longicornis (๑) and Centropages hamatus (O). Alloxanthin content (mean \pm SE) during the AMORE 2000-2001 cruises
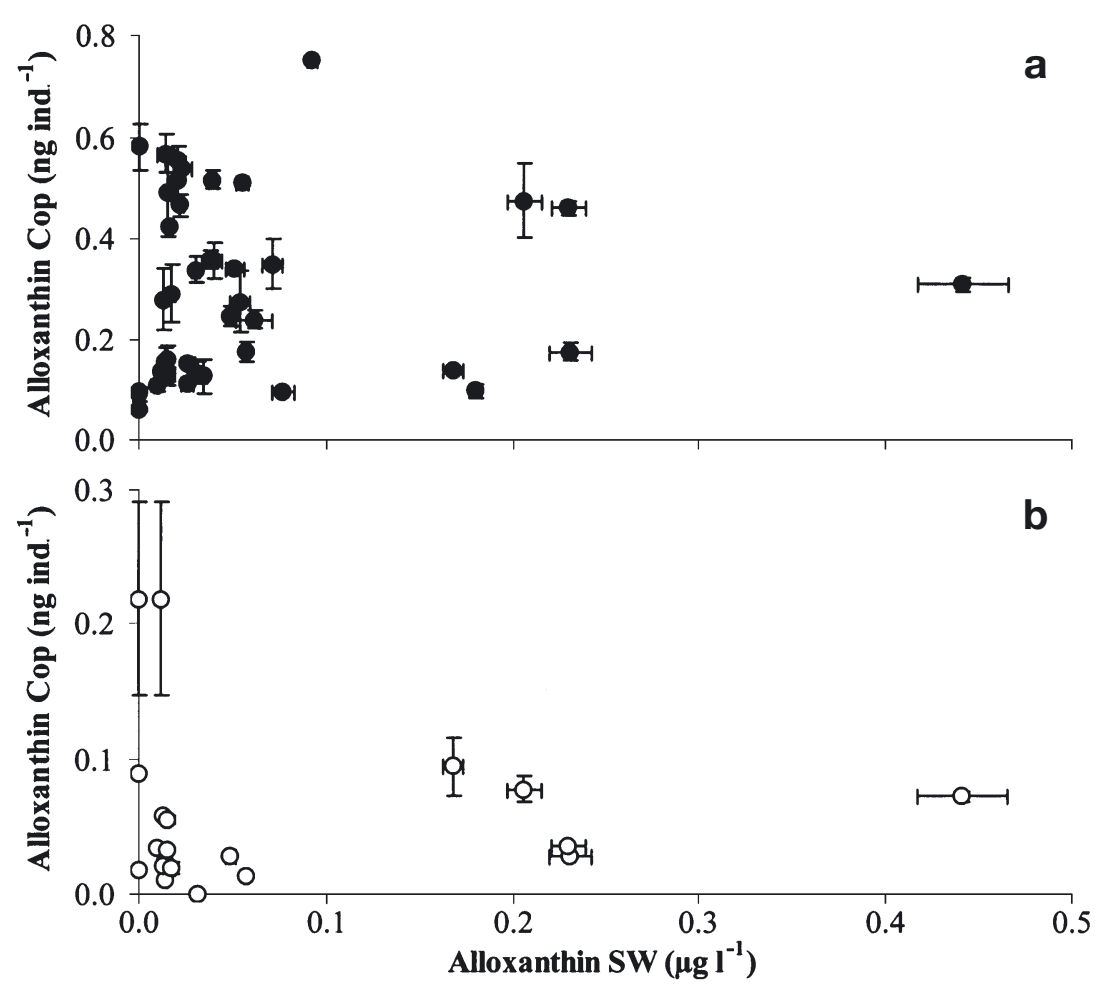

Fig. 5. (a) Temora longicornis and (b) Centropages hamatus. Relation between alloxanthin concentration in seawater (SW) and alloxanthin content of copepods (Cop) (mean \pm SE) during the AMORE 2000-2001 cruises

\section{DISCUSSION}

The significant correlation $(p<0.001)$ between alloxanthin concentration and Cryptophyceae abundance confirms the chemotaxonomic marker quality of the pigment in natural seawater samples as reported in the literature (Gieskes \& Kraay 1983, Jeffrey \& Vesk 1997, Breton et al. 2000). However, the origin of alloxanthin found in the copepods is problematic since (1) no significant correlation was found with alloxanthin in the seawater, and (2) no significant grazing on Cryptophyceae was observed in feeding experiments whereas other potential prey were consumed. In fact, alloxanthin was present in the copepods even when it was not detected in the water (Fig. 5). Such a discrepancy has also been reported by Breton et al. (1999) and Cotonnec et al. (2001), who found that (after fucoxanthin) alloxanthin was the main carotenoid in the body tissues of Temora longicornis, whereas it was not detectable in the seawater samples, and that Cryptophyceae abundance observed by microscopy was low $\left(10^{2}-10^{3}\right.$ cells $\left.1^{-1}\right)$. These observations led the authors to conclude that copepods fed selectively on Cryptophyceae. However, the results of our gutevacuation experiments clearly show that alloxanthin was still present in copepod extracts after several hours of starvation whereas fucoxanthin and chloropigments decreased rapidly with time. If we assume that a chloropigment decrease indicates gutemptying, it can be concluded that most of the detected alloxanthin did not originate from the gut but from body tissues. This conclusion could explain some intriguing laboratory observations reported in the literature. Breton (2000), for instance, reported the presence of alloxanthin in T. longicornis fed on monospecific cultures of diatoms, chlorophytes and Artemia sp. nauplii (which do not contain alloxanthin) and after $3 \mathrm{~h}$ starvation. Likewise, Descy et al. (1999) reported the presence of alloxanthin in a freshwater copepod, Diaptomus minutus, starved for $8 \mathrm{~h}$ in filtered water, and also in copepods that were not fed Cryptophyceae. 

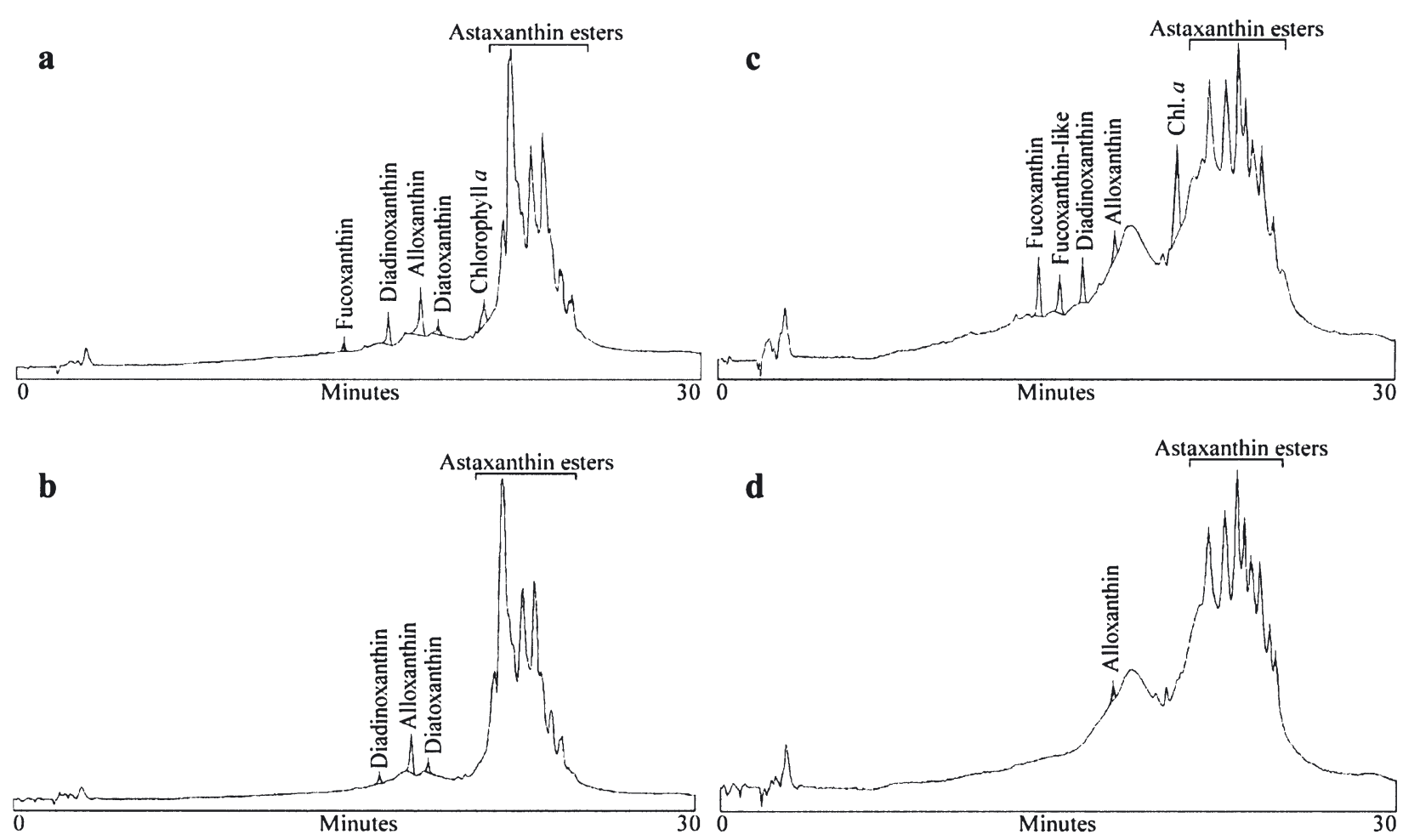

Fig. 6. (a,b) Temora longicornis, $(\mathrm{c}, \mathrm{d})$ Centropages hamatus. Absorbance chromatograms at 436 nm obtained from HPLC analysis of adult copepod extracts (50 individuals) at the beginning $(\mathrm{a}, \mathrm{c})$ and after $90 \mathrm{~min}(\mathrm{~b}, \mathrm{~d})$ of starvation experiment in June 2001

It could be argued that copepod guts were not empty at the end of our starvation experiments and that the disappearance of pigments was due to degradation into colourless compounds. Indeed, fucoxanthin decreased faster than chloropigments, suggesting that a strong degradation of this pigment occurred during gut passage. Such degradation has already been suggested by Kleppel (1998) and is known to affect chloropigments as well (Conover et al. 1986, Head \& Harris 1992, Tirelli \& Mayzaud 1998, Pandolfini et al.

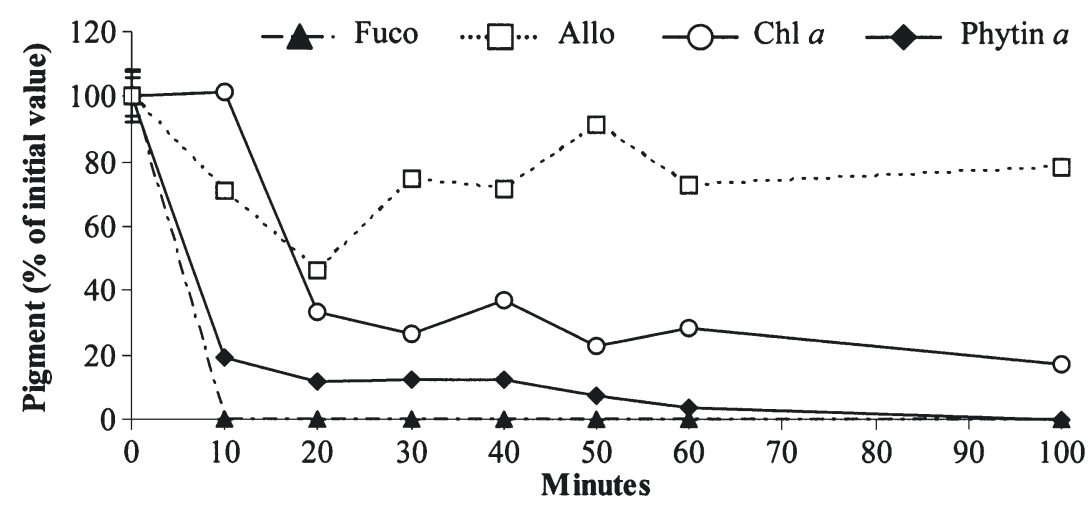

Fig. 7. Temora longicornis. Mean pigment content during 100 min starvation in January 1998
2000). However, this phenomenon does not challenge our assumption of an empty gut after more than $1 \mathrm{~h}$ of starvation, since direct observation of copepods did not reveal any trace of food in the gut. Additionally, if we derive gut passage time from ambient temperature (Dam \& Peterson 1988, Irigoien 1998), we obtain 24 and $39 \mathrm{~min}$ for experiments conducted at 15.7 and $6.3^{\circ} \mathrm{C}$, respectively. Experiment durations (90 and $100 \mathrm{~min}$ ) were consequently long enough to guarantee a complete evacuation of the gut.

Since copepod alloxanthin cannot be localised in gut contents, the question of its origin remains open. At least 3 hypotheses can be proposed: (1) the existence of endosymbiotic Cryptophyceae living in copepod tissues; (2) an accumulation in copepod body tissues of alloxanthin from ingested Cryptophyceae; (3) a metabolic transformation of other ingested pigments into alloxanthin by the copepods themselves. Concerning the first hypothesis, endosymbiotic Cryptophyceae are found in planktonic ciliates such as Mesodinium rubrum (Parsons \& Blackbourn 1968, Hibberd 1977, Gieskes \& Kraay 1983), in dinoflagellates such as 
Gymnodinium acidotum (Wilcox \& Wedemeyer 1984) and in some Dinophysis spp. (Meyer-Harms \& Pollehne 1998, Hackett et al. 2003), but not in copepods. The fact that other pigments usually found in Cryptophyceae were not detected in starved copepods make this hypothesis very speculative, but it cannot be completely excluded since the pigment dynamics of endosymbiotic Cryptophyceae are poorly known. The second hypothesis (accumulation of alloxanthin from ingested Cryptophyceae in copepod tissues) remains possible, since even if Cryptophyceae ingestion is very low (i.e. not detectable using grazing experiments), a whole life-time accumulation could lead to detectable amounts in copepods. Alternatively, copepods could transform other ingested algal carotenoids into alloxanthin. Like all animals, copepods cannot synthesise carotenoids de novo (Goodwin 1960). Thus, if carotenoids which are not present in the diet are found in the copepod tis-
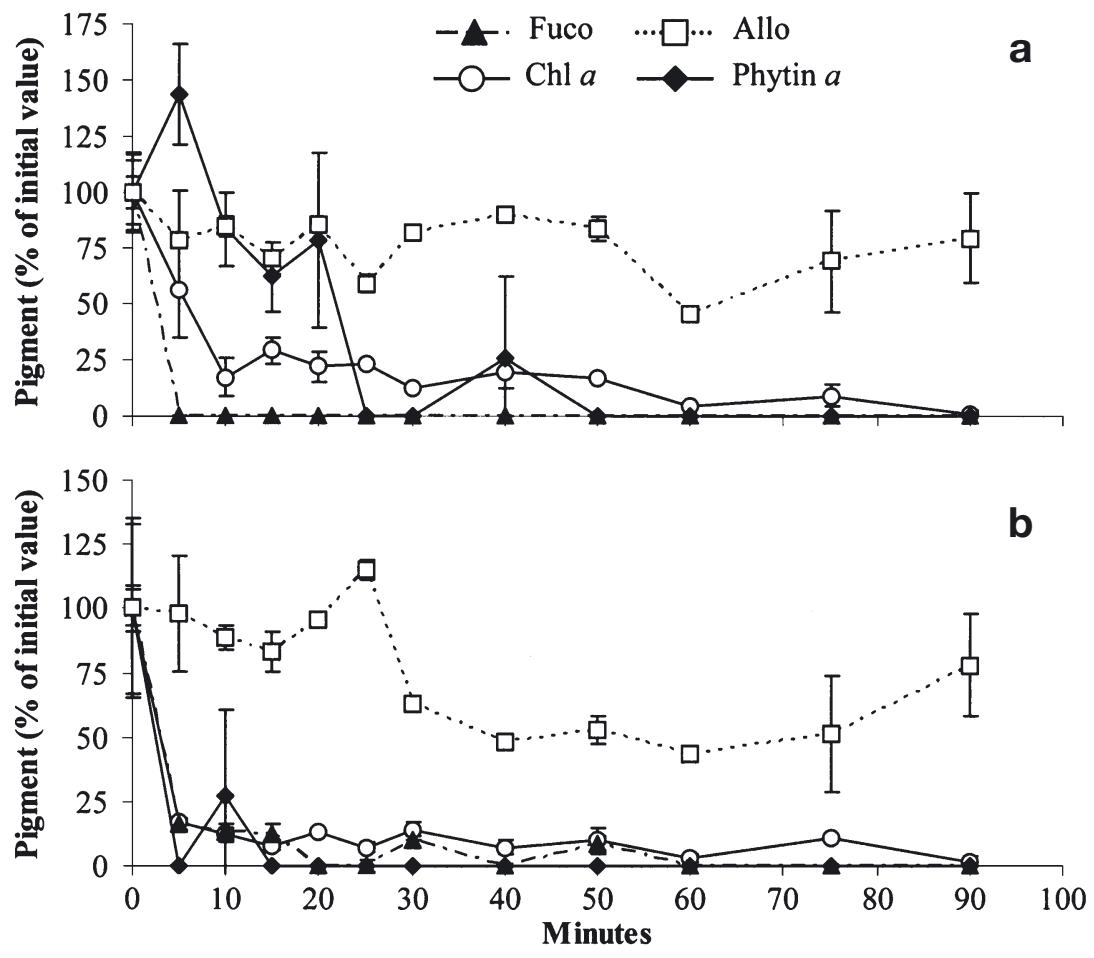

Fig. 8. (a) Temora longicornis, (b) Centropages hamatus. Mean ( \pm SE) pigment content during 90 min starvation in June 2001 sues, they must have been produced from dietary carotenoids by oxidation. Copepods are capable of transforming the $\beta$-carotene and its derivatives present in ingested plant food into their own principal carotenoid, astaxanthin, by oxidative metabolic pathways via the intermediary pigments echinenone and canthaxanthin (Goodwin 1960, 1971, Simpson \& Chichester 1981). Alloxanthin present in copepod body tissues could be an intermediary pigment leading to further metabolic transformation into astaxanthin. Indeed, alloxanthin has already been reported as a possible metabolic pathway to astaxanthin in goldfish Carassius auratus teguments (Ohkubo et al. 1999).

Our results do not permit a choice among the hypotheses considered or a combination of them, and further experiments will be necessary to elucidate the origin of alloxanthin in copepod bodies. In any case, our results suggest that alloxanthin is not suitable as a biomarker for quantitative or qualitative estimates of copepod grazing on Cryptophyceae. As a consequence, reports of alloxanthin in copepod extracts as evidence of Cryptophyceae ingestion (i.e. Breton et al. 1999, Cotonnec et al. 2001) need to be reconsidered. Furthermore we argue that copepod biomass may at times represent a substantial source of alloxanthin in the water column. A single copepod may contain sufficient alloxanthin in its gut to overshadow the Cryptophyceae alloxanthin in water samples. Thus, precautions must be taken to remove copepods from water

samples before filtering. Similar problems could be encountered with other taxon-specific pigments such as echinenone and lutein, which are sometime recorded in small amounts in copepod tissues (Lotocka \& Styczynska-Jurewicz 2001).

Acknowledgements. We thank the crews of RV 'Belgica' and RV 'Zeeleeuw' for their assistance during the sampling campaigns. This work is a contribution to the AMORE (Advanced MOdelling and Research on Eutrophication) project of the Belgian programme 'Scientific Support Plan for a Sustainable Development Policy-Sustainable Development of the North Sea' funded by the Federal Office of Scientific, Technical and Cultural affairs under contract \# SSTC/DD/20-21. We are grateful to Dr J. Dolan for his advice and helpful discussion and for critically reading the manuscript.

\section{LITERATURE CITED}

Breton E (2000) Qualité du pool nutritif et nutrition des copépodes pélagiques en Manche orientale. $\mathrm{PhD}$ thesis, University of Lille

Breton E, Sautour B, Brylinski JM (1999) No feeding on Phaeocystis sp. as solitary cells (post bloom period) by the copepod Temora longicornis in the coastal waters of the English Channel. Hydrobiologia 414:13-23

Breton E, Brunet C, Sautour B, Brylinski JM (2000) Annual variations of phytoplankton biomass in the eastern English Channel: comparison by pigment signatures and microscopic counts. J Plankton Res 22:1423-1440

Brunet C, Brylinski JM, Bodineau L, Thoumelin G, Bentley D, 
Hilde D (1996) Phytoplankton dynamics during the spring bloom in the southern-eastern English Channel. Estuar Coast Shelf Sci 43:469-483

Colijn F, Villerius L, Rademaker M, Hammer KD, Eberlein K (1990) Changes in spatial distribution of primary production, photosynthetic pigments and phytoplankton species composition during two surveys in the German Bight. Neth J Sea Res 25:155-164

Conover RJ, Durvasula R, Roy S, Wang R (1986) Probable loss of chlorophyll-derived pigments during passage through the gut of zooplankton, and some of the consequences. Limnol Oceanogr 31:878-887

Cotonnec G, Brunet C, Sautour B, Thoumelin G (2001) Nutritive value and selection of food particles by copepods during a spring bloom of Phaeocystis sp. in the English Channel, as determined by pigment and fatty acid analyses. J Plankton Res 23:693-703

Dam HG, Peterson WT (1988) The effect of temperature on the gut clearance rate constant of planktonic copepods. J Exp Mar Biol Ecol 123:1-14

Daro MH (1988) Migratory and grazing behavior of copepods and vertical distribution of phytoplankton. Bull Mar Sci 43: 710-729

Descy JP, Frost TM, Hurley JP (1999) Assessment of grazing by the freshwater copepod Diaptomus minutus using carotenoid pigments: a caution. J Plankton Res 21: $127-145$

Fransz HG, Mommaerts JP, Radach G (1991) Ecological modelling of the North Sea. Neth J Sea Res 28:67-140

Frost BW (1972) Effects of size and concentration of food particles on the feeding behavior of the marine planktonic copepod Calanus pacificus. Limnol Oceanogr 17:805-815

Gasparini S, Daro MH, Antajan E, Tackx M, Rousseau V, Parent JY, Lancelot C (2000) Mesozooplankton grazing during the Phaeocystis globosa bloom in the southern bight of the North Sea. J Sea Res 43:345-356

Gieskes WWC, Kraay GW (1983) Dominance of Cryptophyceae during the phytoplankton spring bloom in the central North Sea detected by HPLC analysis of pigments. Mar Biol 75:179-185

Gieskes WWC, Kraay GW (1984) Phytoplankton, its pigments and primary production at a central North Sea station in May, July and September 1981. Neth J Sea Res 18:51-70

Goodwin TW (1960) Biochemistry of pigments. In: Waterman TH (ed) The physiology of crustacea, Vol I, Metabolism and growth. Academic Press, New York, p 101-140

Goodwin TW (1971) Pigments - Arthropoda. In: Florkin M, Scheer BT (eds) Chemical zoology. Academic Press, New York, p 279-288

Hackett JD, Maranda L, Yoon HS, Bhattacharya D (2003) Phylogenetic evidence for the cryptophyte origin of the plastid of Dinophysis (Dinophysiales, Dinophyceae). J Phycol 39:440-448

Head EJH, Harris LR (1992) Chlorophyll and carotenoid transformation and destruction by Calanus spp. grazing on diatoms. Mar Ecol Prog Ser 86:229-238

Hibberd DJ (1977) Observations on the ultrastructure of the cryptomonad endosymbiont of the red-water ciliate Mesodinium rubrum. J Mar Biol Assoc UK 57:45-61

Irigoien X (1998) Gut clearance rate constant, temperature and initial gut contents: a review. J Plankton Res 20: 997-1003

Jeffrey SW, Vesk M (1997) Introduction to marine phytoplankton and their pigment signatures. In: Jeffrey SW, Mantoura RFC, Wright SW (eds) Phytoplankton pig-

Editorial responsibility: Otto Kinne (Editor),

Oldendorf/Luhe, Germany ments in oceanography: guidelines to modern methods UNESCO, Paris, p 37-84

Jeffrey SW, Mantoura RFC, Bjørnland T (1997) Part IVData for the identification of 47 key phytoplankton pigments. In: Jeffrey SW, Mantoura RFC, Wright SW (eds) Phytoplankton pigments in oceanography: guidelines to modern methods. UNESCO, Paris, p 449-555

Jeffrey SW, Wright SW, Zapata M (1999) Recent advance in HPLC pigment analysis of phytoplankton. Mar Freshw Res 58:879-896

Kleppel GS (1998) The fate of the carotenoid pigment fucoxanthin during passage through the copepod gut: pigment recovery as a function of copepod species, season and food concentration. J Plankton Res 20:2017-2028

Lancelot C, Keller MD, Rousseau V, Smith WO, Mathot S (1998) Autoecology of the marine haptophyte Phaeocystis sp. In: Anderson DM, Cembella AD, Hallegraeff GM (eds) Physiological ecology of harmful algal blooms. NATO ASI Ser G, Vol 41, Springer, Berlin, p 209-224

Lotocka M, Styczynska-Jurewicz E (2001) Astaxanthin, canthaxanthin and astaxanthin esters in the copepod Acartia bifilosa (Copepoda, Calanoida) during ontogenetic development. Oceanologia 43:487-497

Menden-Deuer S, Lessard E (2000) Carbon to volume relationships for dinoflagellates, diatoms, and other protist plankton. Limnol Oceanogr 45:569-579

Menden-Deuer S, Lessard E, Satterberg J (2001) Effect of preservation on dinoflagellate and diatom cell volume and consequences for carbon biomass predictions. Mar Ecol Prog Ser 222:41-50

Meyer-Harms B, Pollehne F (1998) Alloxanthin in Dinophysis norvegica (Dinophysiales, Dinophyceae) from the Baltic Sea. J Phycol 34:280-285

Ohkubo M, Tsushima M, Maoka T, Matusno T (1999) Carotenoids and their metabolism in the goldfish Carassius auratus (Hibuna). Comp Biochem Physiol B 124:333-340

Pandolfini E, Thys I, Leporcq B, Descy JP (2000) Grazing experiments with two freshwater zooplankters: fate of chlorophyll and carotenoid pigments. J Plankton Res 22: 305-319

Parsons TR, Blackbourn DJ (1968) Pigments of the ciliate Mesodinium rubrum (Lohmann). Neth J Sea Res 4:27-31

Reid P, Lancelot C, Gieske WWC, Hagmeier E, Weichart G (1990) Phytoplankton of the North Sea and its dynamics: a review. Neth J Sea Res 26:295-331

Rousseau V, Mathot S, Lancelot C (1990) Calculating carbon biomass of Phaeocystis sp. from microscopic observations. Mar Biol 107:305-314

Rousseau V, Leynaert A, Daoud N, Lancelot C (2002) Diatom succession, silicification and silicic acid availability in Belgian coastal waters (Southern North Sea). Mar Ecol Prog Ser 236:61-73

Simpson KL, Chichester CO (1981) Metabolism and nutritional significance of carotenoids. Annu Rev Nutr 1: 351-374

Tirelli V, Mayzaud P (1998) Gut pigment destruction by the copepod Acartia clausi. J Plankton Res 20:1953-1961

Wilcox LW, Wedemeyer GJ (1984) Gymnodinium acidotum Nygaard (Pyrrophyta), a dinoflagellate with an endosymbiotic cryptomonad. J Phycol 20:236-242

Wright SW, Jeffrey SW, Mantoura RFC, Llewellyn CA, Bjørnland T, Repeta D, Welschmeyer N (1991) Improved HPLC method for the analysis of chlorophylls and carotenoids from marine phytoplankton. Mar Ecol Prog Ser 77: 183-196

Submitted: October 23, 2003; Accepted: February 24, 2004

Proofs received from author(s): June 11, 2004 